\title{
MEDIA(TED) DISCOURSE AND SOCIETY
}

\section{Anabela Carvalho}

To cite this article: Anabela Carvalho (2008) MEDIA(TED) DISCOURSE AND SOCIETY, Journalism Studies, 9:2, 161-177, DOI: 10.1080/14616700701848162

To link to this article: http://dx.doi.org/10.1080/14616700701848162

\section{曲 Published online: 13 Mar 2008.}

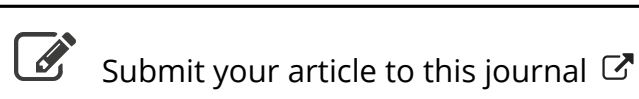

\section{Article views: 2142}

Q View related articles ¿

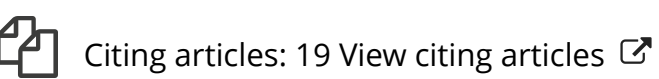




\title{
MEDIA(TED) DISCOURSE AND SOCIETY Rethinking the framework of Critical Discourse Analysis
}

\author{
Anabela Carvalho
}

The analysis of journalistic discourse and its social embeddedness has known significant advances in the last two decades, especially due to the emergence and development of Critical Discourse Analysis. However, three important aspects remain under-researched: the time plane in discourse analysis, the discursive strategies of social actors, and the extra- and supra-textual effects of mediated discourse. Firstly, understanding the biography of public matters requires a longitudinal examination of mediated texts and their social contexts but most forms of analysis of journalistic discourse do not account for the time sequence of texts and its implications. Secondly, as the media representation of social issues is, to a large extent, a function of the discursive construction of events, problems and positions by social actors, the discursive strategies that they employ in a variety of arenas and channels "before" and "after" journalistic texts need to be examined. Thirdly, the fact that many of the modes of operation of discourse are extra- or supra-textual calls for a consideration of various social processes "outside" the text. This paper aims to produce a theoretical and methodological contribution to the integration of these issues in discourse analysis by proposing a framework that combines a textual dimension with a contextual one.

KEYWORDS comparative-synchronic analysis; Critical Discourse Analysis; discursive effects; discursive strategies; historical-diachronic analysis; time

\section{Introduction}

Given the centrality of language to journalism, understanding how it is used in the construction of meaning has for a long time been a natural concern among media scholars. Taking studies of journalistic language in a broad sense, several research traditions can be identified. Both the Glasgow University Media Group and the Birmingham Centre for Contemporary Cultural Studies produced significant interpretive work on the media's representations of social issues from the late 1970s (e.g. Glasgow University Media Group, 1980; Hall et al., 1980). In the field of semiotics, Hartley (1982), Hodge and Kress (1988), and Kress and van Leeuwen (1990) conducted revealing analyses of various types of media messages. Fowler (1991) examined linguistic aspects of news language, such as transitivity in syntax, lexical structure, modality and speech acts, and van Dijk (1988a, 1988b, 1991) and Fairclough (1995) have proposed some of the most systematic analyses of journalistic discourse (or language use). Writing from the perspective of Critical Discourse Analysis (CDA), the two latter scholars have advanced a research programme that involves questioning the role of discourse in the production and transformation of social representations of reality, as well as social relations.

CDA has set itself the goal of looking beyond texts and taking into account institutional and sociocultural contexts. In the analysis of journalistic practices, this task is 
particularly challenging given the fact that journalism intersects with all fields of society. Developing a research programme that encompasses all the moments in the "life" of a particular news text as well as the wider picture of the media discourse produced on a given topic is therefore a key but unaccomplished goal of the CDA research community (cf. Richardson, 2007, for a recent contribution to this end). ${ }^{1}$ This article aims to review the legacy of CDA and identify aspects that could be addressed more satisfactorily in the analysis of media(ted) discourse as well as to contribute to improving such analysis. ${ }^{2}$ It starts with a discussion of the main tenets of CDA, puts forth three related epistemological concerns and proposes a methodological programme for the analysis of journalistic texts.

\section{Revisiting Critical Discourse Analysis}

CDA is the single most authoritative line of research regarding the study of media discourse. Teun van Dijk (e.g. 1988a, 1988b, 1991, 2005), Norman Fairclough (e.g. 1995, 1998, 2003) and Ruth Wodak (e.g. Wodak, 1996; Wodak et al., 1999; Wodak and Chilton, 2005) are the most prominent representatives of this branch of discourse analysis, with media discourse having been thoroughly examined by the first two.

Western Marxism, as represented by Gramsci (1971), Althusser (1971) and the Frankfurt school, is an important backdrop of CDA. It adjoins a certain epistemology of critique brought by "critical social theory" ${ }^{3}$ with a thorough consideration of the means of linguistic construction of sense, and critical linguistics is certainly a crucial influence in the field. Fowler $(1991)^{4}$ was one of the pioneers of the "critical" approach to language in the news. Attempting to go beyond a traditionally "descriptive" discipline of linguistics he brought in issues of power and ideology to the analysis of news reports.

CDA scholars share a distinctive concern with the relations between texts and social processes, as well as with the relations between analysis and the practices analysed. Discourse is viewed as a type of social practice. Each discursive event is dialectically tied to society insofar as it both constitutes and is constituted by social phenomena. CDA often involves a search for aspects or dimensions of reality that are obscured by an apparently natural and transparent use of language. The researcher then tends to be alert to power relations being exercised through discourse and aims to overcome the normal opacity of social practices (Fairclough, 1995, p. 54). S/he wants to expose the causes and consequences of specific discourses and to denounce the social, cultural or political wrongs which they sustain. CDA is then a reflexive and engaged form of social theory, which is wary of its potential implications for social and political formations (Chouliaraki and Fairclough, 1999).

While being a fertile and stimulating field, CDA is not universally or entirely applauded. Amongst its critics, some have claimed that it is flawed or ideologically committed (Tyrwhitt-Drake, 1999), ${ }^{5}$ while others have suggested that its methodological diversity should be overcome (Toolan, 1997). Widdowson (e.g. 1995) and Stubbs (1997) have accused CDA of doing interpretation, not analysis, to which Fairclough (1996; also Chouliaraki and Fairclough, 1999) has contended that the kind of interpretive work that CDA offers is closer to explanation than subjective understanding. Most of these criticisms do not diminish the theoretical and analytical value of CDA. Methodological pluralism, for instance, can be seen as a strength rather than a weakness, and ideological commitment, as discussed above, is an explicit agenda of CDA and does not equal analytical distortion. 
Philo (2007) has recently argued in favour of an integrated analysis of content and processes of production, reception and circulation, and claimed that CDA has not been able to account for the full cycle of news discourse. As suggested above, this is a valid, if nearly unsolvable, point. In this article, I will focus on three aspects that, despite the achievements of CDA, are still lacking satisfactory answers: the time plane in discourse analysis, the discursive strategies of social actors and the effects of mediated discourse.

\section{The Time Plane in Discourse Analysis of Journalistic Texts}

Until recently, time had largely been unaccounted for in the existing literature on discourse analysis of journalistic texts. Most forms of analysis do not express awareness of the time sequence of texts nor do they clearly explain the implications of previous discursive positions on subsequent ones. Hyatt has recently argued for an analysis of temporal context in critical discourse analysis and suggested considering the following aspects:

immediate and medium-term sociopolitical contexts, the contemporary sociopolitical individuals, organizations and structures and the more long-term temporal context which includes the various assumptions of order, structures of inclusion and exclusion and generally how a society legitimates itself and achieves its social identity. (2005, p. 515)

Hyatt's suggestion is similar to the analysis of the social context of discourse which has been a central aspect of CDA's programme at least since the publication of Norman Fairclough's Language and Power (1989). Fairclough's (1995) proposal to examine "sociocultural practice" surrounding media discourse involves analysing the "situational context", the "institutional context" and the "socio-cultural context". Most analyses have not fully accomplished this. Recently, van Dijk has argued that an "explicit theory of context" is still missing and acknowledged the difficulties of contextual analysis.

The fundamental problem ... is how to put constraints on such a "contextual" or "situational" study. Indeed, how do we know or decide where to begin and where to stop such an analysis, since obviously it may begin with details of the interaction, the properties of speakers or of settings, but may stretch to such vast societal "contexts" as contemporary capitalism, neoliberalism, globalization, patriarchy, postmodernism, and so on. That is, if contextual analysis should be relevant, it is crucial not only to define possible contexts, but especially to limit them. (van Dijk, 2004)

The historical nature of discourse is one of its most fundamental characteristics. Texts always build on previous ones, taking up or challenging former discourses. Fairclough (1995) and others have conceptualized these relations as intertextuality. Intertextuality is an important contribution to the study of discourse but does not, per se, give a full account of the time plane, or of the historicity of discourse (Blommaert and Bulcaen, 2000). By looking at the moments of production and consumption of the text, van Dijk (1988b) offers a biography of the text. But the relation between that text and others throughout a period of time is not addressed in his conceptualization.

A biography of social and political issues in the media is missing. When it is taken up, research on change in media discourse has been mainly oriented to issues of style and 
genre (e.g. Fairclough, 1995; Weymouth, 1998), rather than to change in the meaning of issues in the media.

The most significant contribution to the study of time in discourse processes has been advanced by Ruth Wodak and colleagues. Applied to the study of processes of discrimination (van Leeuwen and Wodak, 1999) and national identity (Wodak et al., 1999), their "discourse-historical" approach attempts to account for the historical background of discursive events and explore changes in discourse throughout time (Wodak, 1999). However, media discourse has not yet been examined in detail in this way.

Most studies of media discourse are like snapshots examining some news items in detail but covering a short time span (often only a day or a few days). While this may be relevant for some events, most public issues have a significantly long "life", which is tied to representations in the media. Understanding the evolution of matters such as war, terrorism or climate change, and the ways they are interdependent in relation to the media, is one of the most important contributions to be made by social researchers. There are hurdles to doing this. Examining the various stages of the public life of such issues, from the conditions of emergence in the public arena to their constitution into political problems, formulation of answers, adoption of measures, implementation and evaluation, requires analysing media(ted) discourses for a relatively long period of time. Obviously, this means a large amount of work and man-hours, and researchers need to devise ways of making this feasible.

Besides tracing the history of public issues (the sequence of texts appearing in the media and the evolution of their meaning), a time-sensitive discourse analysis also means considering the particular context of a given period, from specific events and developments related to the issue under examination to wider aspects of the social environment.

Finally, time also matters along the synchronic axis and researchers should take simultaneous discourses into account as comparison contributes to critical analysis. Both the historical-diachronic and the comparative-synchronic perspectives advocated here will be explained below in more detail.

\section{Discursive Strategies of Social Actors}

Journalism is typically a discursive re-construction of reality. Rarely do journalists witness events or get to know reality in a way that does not involve the mediation of others. A variety of social actors serve as sources of information for media professionals, in a direct or indirect way (e.g. Ericson et al., 1989), and the media representation of social issues seems to be very much a function of the initiative of social actors to organize their claims and to project attention to "happenings" and problems (e.g. Anderson, 1997; Spector and Kitsuse, 1977). The media's depictions of social problems will obviously depend largely on the preferences and options of media professionals, including the news values in operation (e.g. Gans, 1979), but necessarily build on the ways other social actors construct issues in their multifarious discourses.

A good method of discourse analysis should account for those two levels of discursive intervention over a certain "object" - the sources' or social actors' intervention, and the journalists' intervention. In war situations, for example, a systematic analysis of the discourse of conflicting parties, as well as of social actors opposing the war, would help understanding and making explicit the alignment of news media with a given side and 
increase awareness of the plurality of views, as well as of the biases both in the media and in social actors' discourses. ${ }^{6}$

van Dijk (e.g. 1988a, 1988b) focuses on the journalist's cognitive processes and on the journalistic text but does not examine the previous discourses of other social actors. Although Fairclough (e.g. 1995) accounts for intertextuality and the progressive transformations of texts along discursive chains, the analysis of the strategies that social actors adopt to construct issues for the media is also missing in his work. This article argues for a renewed attention to be paid to the role of actors' discursive strategies in media discourse. It is important to study the ways they and their standings are represented in the media and in order to do that we must analyse their own discursive strategies in the construction of reality.

\section{Extra- and Supra-textual Effects (or Modes of Operation) of Discourse}

What consequences do texts have for the whole of a discursive field? How does discourse impact on and shape the evolution of social and political issues? For example, how have George W. Bush's speeches on the "war on terror" influenced media discourses on terrorism and expectations of ensuing action? How did this impact on institutional mechanisms and material practices in the United States and other countries?

Wodak and Meyer (2001, p. 66) have argued that there is a "dialectical relationship between particular discursive practices and the specific fields of action (including situations, institutional frames and social structures), in which they are embedded". A constitutive view of discourse has to encompass the analysis of discourse's concrete means of effect. While discourse analysts have concentrated attention on the text, many of discourse's modes of operation are extra- or supra-textual, i.e. they are realized beyond or independently of a given text. Media discourse is an especially important arena for social and political action; yet, studies of media discourse have not spelt out the ways the media shape social realities extra- or supra-textually as explicitly as they could have done. ${ }^{7}$

To address the issue of extra- and supra-textual modes of operation of discourse, I propose the category of discursive effects. ${ }^{8}$ Discursive effects are processes that are linked to texts, but occur outside the text or "above" it; they cannot be "found" in one single text. Moreover, discursive effects are not the direct consequence of one actor's discursive interventions but are often dependent on a variety of (discursive) causes and circumstances and show the constraining force of discourse. Examples of discursive effects are discourse structuration, discourse institutionalization and closure. Discourse structuration refers to the process of domination of the terms of the debate (cf. Hall et al.'s, 1978 , notion of "primary definition"). This may be intended but does not only depend on an actor's construction of an issue and its realization involves more than one text. The discourse of the American administration clearly had an effect of structuration of the discourse of many media outlets, from Fox to the New York Times, in the period that followed the events of September 11, 2001. Discourse institutionalization is the transformation of institutional structures and/or practices in a way that embodies a certain discourse. ${ }^{9}$ Although the process of discourse institutionalization may result from, and originate in certain texts, it usually also has an extra-textual ${ }^{10}$ dimension. One example is the adoption of legal instruments such as the US Patriot Act as a result of certain securitarian discourses on terrorism. Closure is the resolution or termination of some form 
of controversy, for instance in a scientific or policy debate. It is a supra-textual process. The analysis of discursive effects will be integrated in the diachronic analysis proposed below.

\section{Developing an Analytical Framework for Media Discourse}

Chouliaraki and Fairclough (1999) argue that CDA begins from the perception of a problem in society. Many social problems, such as a war or public resistance to genetically modified organisms, have temporal markers and identifying them is the first step to start collecting media(ted) texts on such issues. The constitution of a corpus of news texts depends on a variety of factors and on research goals (e.g. human resources involved in a research project, nature of the social issue being studied, number of media to be analysed). Once this is done, starting with an open-ended reading of texts without very specific questions or hypotheses constraining the analysis can produce interesting results since it allows for the identification of the most significant characteristics of the data, without the filter-effect of a tight research programme.

Critical thinking is crucial at this phase. A "spirit of scepticism" should be adopted, leading to the "suspension of belief in the taken for granted" and "render[ing] the familiar strange" (Gill, 2000, p. 178). Some of the questions that may come to mind are: Why do some things get said and others do not? How are things said and what are the possible implications of that? What is absent from a particular text (factual data, arguments, points of view, etc.)? The first reading of the data will help identify significant debates, controversies, and silences, and possibly suggest specifications and amendments to initial research goals and questions. This open-ended reading should be done for every text in an initial period of the corpus and from then on for a set of texts that can be selected by a multi-stage and stratified random sampling process: articles may be sampled within each news outlet and re-sampled in the peak periods of coverage. In addition to this, the analyst should pay close attention to headlines and the first one or two paragraphs of all the articles that constitute the corpus.

In projects that involve large amounts of data, the second step is to circumscribe the number of texts to be subjected to discourse analysis. A formula for re-selection needs to be designed. The combination of comprehensive (exhaustive) analysis in selected periods with analysis of "critical discourse moments" (Chilton, 1987; Gamson, 1992) is a potentially fruitful option. On the one hand, there are periods that are determining in the construction of an issue and therefore call for an integral analysis. For example, this is the case of the first few years of coverage of climate change in the media (1988-9) when it was transformed from a low-attention issue into a significant political and public issue. On the other hand, after some time, discursive constructions of an issue start sedimenting and the amount of novelty decreases, while given discursive positions start being more and more recurrent. It, therefore, makes sense to suspend the article-by-article analysis and "jump" to the next "critical discourse moment".

Critical discourse moments are periods that involve specific happenings, which may challenge the "established" discursive positions. Various factors may define these key moments: political activity, scientific findings or other socially relevant events. The construction of a chronology of events relevant to the issue being analysed can be a useful guideline for identifying critical discourse moments. Questions to be asked about critical discourse moments include: Did arguments change? Did new/alternative views arise? 
From here we turn to the detailed discourse analysis of texts. Below a framework for the analysis of media discourse is outlined. It first focuses on the unit of analysis (that is, each individual text) and then proceeds to its wider context. This framework has been mainly conceived for journalistic texts where written language is dominant (if not exclusive), such as newspaper or magazine articles. Nevertheless, with a few adaptations, it can be applied to other types of news texts, such as televised news reports or online news.

\section{Framework for Analysis of Media Discourse}

I. Textual analysis

1. Layout and structural organization

2. Objects

3. Actors

4. Language, grammar and rhetoric

5. Discursive strategies

6. Ideological standpoints

II. Contextual analysis

1. Comparative-synchronic analysis

2. Historical-diachronic analysis

\section{Textual Analysis}

The dimensions of the text that matter the most in the construction of meaning and that should be analysed are detailed below.

\section{Layout and Structural Organization}

"Surface" elements of the newspaper and of the text itself, such as the section in which the article was published, the page number, the size of the article, and whether it was accompanied by visual elements (photographs, graphics or others), say something about the valuation and categorization of the issue by a given news outlet, with implications for the audience's perception.

The structural organization of the text plays a key role in the definition of what is at stake, as well as in the overall interpretation of an issue. As highlighted by van Dijk (e.g. 1988b), the headline marks the preferred reading of the whole article and should therefore be carefully examined. The lead and the first few paragraphs of the article also deserve close attention.

\section{Objects}

The second question to ask is: which objects does the text construct? The notion of "objects" is close to topics or themes. However, the term "object" has the advantage of enhancing the idea that discourse constitutes rather than just "refers to" the realities at stake. Objects of discourse are not always obvious, and clearly identifying them is an important step towards deconstructing and understanding the role of discourses. In the case of climate change, for example, the broader objects to be constructed may be economics, government or nature. More specific ones may be, for instance, how climate 
change impacts on agriculture. A related question to be asked at this stage of the analysis is: what events/specific issues are associated to the broader issue under consideration? This question is particularly relevant for complex issues like climate change, which has many dimensions, and therefore can be tackled from many angles and perspectives. ${ }^{11}$ Mapping the links reporters (and other authors) make between specific events, such as the option for a new road programme and climate change, can be very illuminating vis-à-vis the political standing of a certain discourse (the fact that an author does not make such links is just as meaningful).

\section{Actors}

Who does the article mention? How are those actors represented? ${ }^{12}$ Here we are interested in the individuals or institutions that are either quoted or referred to in the text. $^{13}$ The term "actors" in this analysis means both social agents (someone who has the capacity of doing something) and characters in a (staged) story (which is ultimately what news reports are).$^{14}$ Actors are then both subjects - they do things - and objects - they are talked about. They may appear as isolated figures or in "discourse coalitions" (Hajer, 1995).

Texts play a major role in constructing the image of social actors, as well as in defining their relations and identities (Fairclough, 1995; Halliday, 1978, 1985). An essential aspect in the study of actors in texts is their perceived influence in shaping the overall meaning of the text. Whose perspective seems to dominate? What is the "framing power" of social actors in relation to the media? Framing power may be defined as the capacity of one actor to convey her/his views and positions through the media, by having them represented by journalists either in the form of quotes or regular text. Having the predominant framing power in relation to a certain issue is an important form of social influence. But we must bear in mind that such framing power is crucially yielded or denied by journalists (e.g. White, 1950), who hold a major power of discursive construction of social issues. ${ }^{15}$

The analysis of the representation of actors in the media is closely related to the analysis of the representation of their discursive strategies (see below).

\section{Language, Grammar and Rhetoric}

The identification of key concepts and of their relationship to wider cultural and ideological frameworks is an important part of discourse analysis (e.g. Jacobs and Manzi, 1996). Furthermore, the vocabulary used for representing a certain reality (e.g. verbs, adjectives, adverbs) and the writing style (e.g. formal/informal, technical, conversational) are important dimensions of the constitution of meanings. Linguistic analyses of journalistic texts pay close attention to issues of pragmatics, semantics and syntax in discourse in a much more detailed manner (e.g. Fowler, 1991). Such is not the focus of this framework and the analysis of language will be limited to the aspects listed above (concepts, vocabulary/lexical choices and style).

As maintained by most CDA scholars, the study of a text's grammar can reveal many of its underlying (ideological) presuppositions. Nominalizations and active/passive sentences are among the most important syntactic features in news discourse. 
Finally, we look at metaphors, other rhetorical figures and persuasive devices employed in the text (cf. van Dijk, 1988b). An emotionally charged discourse, with an appeal to readers' emotions, for instance, is often found in the press, and can have an important rhetorical role. ${ }^{16}$ In the analysis of language and rhetoric we look, on the one hand, at the formulations advanced by social actors, and on the other hand, at the discourse of journalists.

\section{Discursive Strategies}

Discursive strategies are forms of discursive manipulation of reality by social actors, including journalists, in order to achieve a certain effect or goal. Here, manipulation does not have the sense of an illegitimate alteration of a certain reality (cf. van Dijk, 2006). Rather, I use the term to mean, simply, a discursive intervention. This intervention and the procured aim can be more or less conscious (cf. Wodak, 1999; Wodak et al., 1999). ${ }^{17}$

The notion of discursive strategies helps us perceive the link between "source strategies" and media representations (e.g. Anderson, 1997). Pointing to the enabling power of discourse, such a notion is also illuminating with regard to the processes of claims-making, for which the media are a crucial arena, and which necessarily involve language uses aiming at "showing", "proving" or "calling attention" to a given point or matter. Nevertheless, systematic inquiries into discursive strategies in the media are extremely scarce in what is an important research gap on media discourse (see Carvalho, 2005 on the strategies of the Guardian, The Times and The Independent regarding climate change).

I will refer below to some of the most significant discursive strategies. The main intervention the speaker/author makes is enacted in the selection of an angle of the (complex) reality s/he is talking about. This is an important part of the act of "framing" a certain reality. I suggest thinking in terms of framing as an action or operation, rather than in terms of frames as (fixed) independent entities. Framing is to organize discourse according to a certain point of view or perspective. In the production of texts, framing involves selection and composition (cf. Entman, 1993). Selection is an exercise of inclusion and exclusion of facts, opinions, value judgements, etc. Composition is the arrangement of these elements in order to produce a certain meaning. I do not view framing as an optional intervention in discourse, unlike other authors (e.g. Durham, 1998). ${ }^{18}$ Instead, it is something inherent to the construction of texts. Framing is not something that you choose to do or not, but a necessary operation in talking about reality. Therefore, what is at stake in the analysis of framing as a discursive strategy is how, and not whether, an actor frames reality.

Turning now to other discursive strategies, I would highlight positioning and, as examples of more specific strategies, legitimation and politicization. Positioning is a discursive strategy that involves constructing social actors into a certain relationship with others, that may, for instance, entitle them to do certain things (cf. Davies and Harré, 1990; Hajer, 1995). Positioning can also be viewed as a wider process of constitution of the identity of the subject through discourse. ${ }^{19}$ Legitimation consists in justifying and sanctioning a certain action or power, on the basis of normative or other reasons (cf. van Leeuwen and Wodak, 1999). Politicization is the attribution of a political nature or 
status to a certain reality, such as climate change. Some of these strategies have a reverse, such as de-legitimation and de-politicization. Naturally, there is a very large number of potential discursive strategies, at different levels of specificity. For instance, while framing is a fundamental and necessary operation, constructing responsibility (in the representation of an accident, for instance) is a much more specific and highly discretionary strategy.

In the analysis of discourse strategies, it is important to discriminate the journalist's strategies from the strategies of other social actors. This is done by examining speeches, press releases, reports, websites and a number of other forms of communication of the social actors involved with a given issue (e.g. politicians, corporations, non-governmental organizations). When primary documents are not available, we can also indirectly "read" the discourse of social actors from quotes and indirect speech in the news. This is obviously a product of the media's selectivity apparatus; however, provided that they are not made up by journalists or others, quotes still "say" something, and a way of "fighting" the effects of the media's filtering processes is triangulation of news organs. The goal is to map discursive strategies in relation to social actors. Which actors use which discursive strategies? How are different actors involved in the discursive strategies of others (how are they constructed by others)?

As suggested above, a key task in analysing media discourse is to understand how the discursive strategies of each (relevant) social actor are reproduced, challenged or excluded. What are the relations between the discursive strategies of each social actor and news discourse? How do news outlets reconstruct the strategies of policy-makers and antiwar activists, for example?

\section{Ideological Standpoints}

The notion that ideologies are embedded in discourses is a central claim of discourse studies, especially "critical" versions like CDA. The concept of ideology is used in many - and often conflicting - senses. Relating ideologies to social and political values associated with stances towards a certain reality, this article argues for a mutually constitutive view of ideology and media(ted) discourses.

Ideological standpoints are possibly the most fundamental shaping influence of a text. ${ }^{20}$ Yet discourse analysis does not always fully reveal them. Fairclough (1995) looks for ideological mechanisms at the level of the implicit, of assumptions and presuppositions in the text and van Dijk claims that "semantic structures of discourse ... form the core 'content' of the expression of ideological opinions" (1998, p. 31). ${ }^{21}$

I would argue that a broader view of the discursive realization of ideology is necessary. Ideology is an overarching aspect of the text. It is embedded in the selection and representation of objects and actors, and in the language and discursive strategies employed in a text. However, one should expect the ideological standpoints of an author not to be always explicit in the text, especially news texts. Appearing natural is at the core of the ideologically shaped work of representing reality in the news media (see Allan, 1999). In the process of newsmaking, "the multi-accentual 'potential for meaning' of the chosen signs ... are filled in until the signs are 'closed', apparently uni-accentual" (Hartley, 1982, p. 63). Identifying the discursive means of such "ideological closure" (Hartley, 1982, p. 63) often requires a good deal of interpretive work. Certainly, in some texts, normative, political and value claims are relatively clear. But the analyst has to learn to identify 
ideological standpoints from relatively subtle mechanisms and devices. Looking at alternative constructions of the same reality (such as different media reports) is a helpful strategy (see comparative-synchronic analysis below). It is important to make ideologies manifest because they involve fundamental motivations and justifications for keeping or changing a certain status quo.

The analysis of both discursive strategies and ideological standpoints in journalistic texts is not independent from the analysis of the other elements enunciated above. The discursive strategies of news professionals are implicated in the layout and structure of the text, in the construction of objects and actors in discourse, and in the language, grammar and rhetoric. In turn, ideological positions have to be inferred from all the other elements, as well as from discursive strategies.

To conclude the section on methodology involved in textual analysis, it is worth emphasizing that we should constantly look for what is present in the text and for what is absent (see Fairclough, 1995). Silence can be as performative as discourse. Texts ought to be read "politically", to use the terms of Carver and Hyvärinen (1997). "Political reading" recognizes that politics is not natural, but "contingent, plural and conflictual" (Carver and Hyvärinen, 1997, p. 6), and aims to maintain in the analysis the awareness of possible alternatives to the dominant position(s). What is obscured in the text? How does the inclusion and exclusion of facts serve the creation of a certain meaning? These are questions that should always be kept in the analyst's mind.

\section{Contextual Analysis}

In a second stage of the analysis, we look beyond the text to the overall coverage of an event or issue in one news outlet and examine the wider social context. The first simple question is: how many texts are dedicated to each event/issue over a given amount of time? The number of texts is a crucial indicator of the importance awarded by a news organ to an issue.

Two time-related dimensions of analysis are considered at this stage - synchronic and diachronic. This is achieved by two main means of inquiry, respectively, comparison and historical analysis. Hence, we pursue a comparative-synchronic analysis and a historicaldiachronic analysis.

\section{Comparative-synchronic Analysis}

Philo (2007, p. 186) has pointed out that "[c]ritical discourse analysis would be more powerful if it routinely included a developed account of alternatives". A comparativesynchronic analysis means looking at various representations of an issue at the time of the writing of one specific news text (the unit of analysis). More specifically, we compare one text with other representations of the issue: texts published on the same day (or another time unit) by different authors, both in the same news outlet and in others. The comparison of different media depictions of reality involves attempting to reconstitute the original events (discursive or non-discursive). By cross-referencing news outlets and checking original documents, such as reports or policy documents, researchers can form their own image of reality, which is hopefully more accurate and/or complete than each individual media representation. As suggested earlier, this is important because it allows 
for a better assessment of the intervention of journalists (or other authors of news texts) in that reality, and of their reconstruction of the discursive strategies of social actors. While the framework proposed here brings in intertextuality in looking at the links between texts produced by social actors and media texts (how one text is integrated into another, the transformations it undergoes), the comparative-synchronic analysis differs from what is normally designated as intertextual analysis. It is a confrontation of alternative depictions of reality that mainly aims to enhance the critical reading of news discourse and help identify the specific discursive traits of a given news outlet.

\section{Historical-diachronic Analysis}

The historical-diachronic analysis takes place at two levels. At a first level, the historical approach involves examining the course of social matters and their wider political, social and economic context (cf. Wodak et al., 1999; van Leeuwen and Wodak, 1999). As several CDA scholars maintain, the historical conditions and the context of production of media(ted) texts have to be accounted for in discourse analysis. ${ }^{22}$ In order to do this, the research must be rather open in theoretical and methodological terms (Weiss and Wodak, 2003). Although not new, a concern with interdisciplinarity in CDA has been made more explicit in the last few years (e.g. Wodak and Chilton, 2005) and, in spite of being very challenging, this is a crucial research avenue to pursue. Bringing the contributions of disciplines such as political science, sociology and psychology to the analysis of media(ted) discourses on Islam and terrorism, for example, may be very productive.

At a second level, it is important to examine the temporal evolution of media(ted) discourses and to produce a history of media constructions of a given social issue. ${ }^{23}$ This involves looking at the sequence of discursive constructions of an issue and assessing its significance. How did representations of reality impact on subsequent ones? How were they reproduced or contested? ${ }^{24}$ What were the political, social and/or cultural implications of dominant discourses? What alternative arguments and proposals were excluded from public agendas and why? Issue-development - the sequence of events and constructions of the issue - is a crucial aspect for understanding the present. The "biographical" study of social and political matters can therefore help make sense of the arrangements that govern us. The identification of discursive effects, as discussed above, is a helpful analytical procedure, and an important part of a historical-diachronic discourse analysis.

\section{Conclusion}

In the tradition of CDA, this article has advanced a framework for researching media discourse that integrates several dimensions of analysis and addresses issues such as time in discourse analysis, the discursive manipulation of reality by different social actors, and the modes of social operation of discourse. The scope of analysis in such an approach is both synchronic and diachronic. It privileges the analysis of continuity (and discontinuity) over the analysis of the episodic. Hence, this approach promotes the comprehensive analysis of media discourse on particular issues over an extended period of time. 
Like any other method, the one that was proposed here generates some difficulties. Because of the preferred wide scope of analysis, the volume of materials to be analysed can be vast. It is therefore unmanageable for a sole researcher to analyse each unit of analysis (e.g. a news article). The suggested solution is to analyse some periods exhaustively and then focus on "critical discourse moments", which seems a more adequate option than random sampling or an arbitrary form of choice of texts. The analysis of those "moments" allows for the identification of discursive turns and/or continued lines of argumentation at particularly important times in the social construction of an issue.

\section{NOTES}

1. Richardson (2007) combines a strong theoretical foundation with a wealth of empirical examples of how the CDA programme can be applied to the discourse of newspapers.

2. The goal is not to make claims in the general field of CDA as the focus here is on the analysis of media(ted) discourses only. Many of the debates on CDA as a whole are therefore relevant for the present discussion but the reverse is not necessarily true.

3. As noted by van Dijk (2001), CDA has counterparts in "critical" developments in the social sciences (e.g. Birnbaum, 1971).

4. Earlier, Fowler et al. (1979) had already set out the "critical linguistics model".

5. Cf. Flowerdew (1999) for a response.

6. Part of the reason for the levels of public opposition to the Iraq war in European countries and elsewhere may be the relative "desintermediation" of communication of the views of different social actors brought about by the internet.

7. Some works on environmental policy-making have provided interesting insights into these issues. Hajer (1995) has referred to discursive mechanisms as processes through which discourse works.

8. Hajer (1995) uses the expression "discourse mechanisms" to refer both to what I have designated as discursive strategies (see below) and to effects, therefore not individuating agency in discourse. His category of "discourse mechanisms" includes a variety of intraand extra-textual (and even extra-discursive) aspects, from "positioning" to "sensory experience".

9. Hajer (1995) claims that discursive hegemony is attained through discourse structuration and discourse institutionalization (cf. Berger and Luckmann, 1991 [1966]).

10. The term "extra-textual" is preferable to "extra-discursive" (cf. Foucault's, 1984, notion of extra-discursive dependencies), given that institutions are, in some respects, a product of discourses.

11. In journalistic terms one can think of news pegs: what events or issues does a particular article "originate" from?

12. van Leeuwen (1996) provides a complex "sociosemantic inventory" of ways to represent social actors.

13. Compare with the notion of "source". Some of those actors may have functioned as sources for the author of the article while others have not.

14. This understanding of actors differs from Fairclough's "voices", which refers to "those speaking or whose speech is represented" $(1995$, p. 80$)$ in the media.

15. This is also related to issues of access to the media. 
16. Of course, rhetorical analysis can be much more encompassing than what is suggested here: for an introduction see, for instance, Gill and Whedbee (1997).

17. Wodak defines "strategies" in discourse as "plans of actions that may vary in their degree of elaboration, may be located at different levels of mental organization, and may range from automatic to highly conscious" (1999, p. 188).

18. In Durham's article framing is seen as reduction(ist) practice undertaken by journalists to make sense of reality in a systematic attempt to identify a single meaning for events (that are often complex and multi-dimensional).

19. Compare with Halliday's (1978) interpersonal function of language, and the relational function of discourse mentioned by Fairclough (1995).

20. This does not mean that there is a logical priority of ideologies over texts. Ideologies are produced by texts and "guide" the production of texts.

21. van Dijk's understanding of ideology (1998b, 1998c), as of discourse, is inextricably linked to cognition.

22. Cf. Fairclough's sociocultural practice (1995).

23. Durant et al. (1998) and McComas and Shanahan (1999) are among the few examples of researchers that have tried to understand the evolution of media discourses on a given subject over time. Focusing respectively on frames in biotechnology and in climate change (meta)narratives (as derived from content analysis of texts in various periods) in the United States, their analyses are predominantly quantitative. In consequence, their work offers little detailed analysis of the discursive means of meaning.

24. Cf. Fairclough's chain relations (1995).

\section{REFERENCES}

ALLAN, StUART (1999) News Culture, Milton Keynes: Open University Press.

ALTHUSSER, LOUIS (1971) Lenin and Philosophy and Other Essays, London: New Left Books.

ANDERSON, ALISON (1997) Media, Culture and the Environment, London: University College Press. BERGER, PETER and LUCKMANN, THOMAS (1991[1966]) The Social Construction of Knowledge: a treatise

in the sociology of knowledge, London: Penguin.

BIRNBAUM, NORMAN (1971) Toward a Critical Sociology, New York: Oxford University Press.

BLOMMAERT, JAN and BULCAEN, CHRIS (2000) "Critical Discourse Analysis", Annual Review of Anthropology 29, pp. 447-66.

CARVAlHo, ANABela (2005) "Representing the Politics of the Greenhouse Effect: Discursive strategies in the British media", Critical Discourse Studies 2(1), pp. 1-29.

CARVER, TERREL and HYVÄRINEN, MATTI (1997) "Introduction", in: Terrel Carver and Matti Hyvärinen (Eds), Interpreting the Political: new methodologies, London: Routledge, pp. 1-6.

CHILTON, PAUL (1987) "Metaphor, Euphemism, and the Militarization of Language", Current Research on Peace and Violence 10, pp. 7-19.

CHOULIARAKI, LILIE and FAIRCLOUGH, NORMAN (1999) Discourse in Late Modernity: rethinking Critical Discourse Analysis, Edinburgh: Edinburgh University Press.

DAVIES, BRONWYN and HARRÉ, ROM (1990) "Positioning: the discursive production of selves", Journal for the Theory of Social Behaviour 20(1), pp. 43-63.

DURANT, JOHN, BAUER, MARTIN and GASKELL, GEORGE (Eds) (1998) Biotechnology in the Public Sphere: a European sourcebook, London: Science Museum Publications.

DURHAM, FRANK (1998) "News Frames as Social Narratives: TWA flight 800", Journal of Communication 48(4), pp. 100-17. 
ENTMAN, ROBERT (1993) "Framing: toward clarification of a fractured paradigm", Journal of Communication 43(4), pp. 6-27.

ERICSON, RICHARD, BARANEK, PATRICIA and CHAN, JANET (Eds) (1989) Negotiating Control: a study of news sources, Milton Keynes: Open University Press.

FAIRCLOUGH, NORMAN (1989) Language and Power, London: Longman.

FAIRCLOUGH, NORMAN (1995) Media Discourse, London: Edward Arnold.

FAIRCLOUGH, NORMAN (1996) "A Reply to Henry Widdowson's "Discourse Analysis: A Critical View"', Language and Literature 5(1), pp. 49-56.

FAIRCLOUGH, NORMAN (1998) "Political Discourse in the Media: an analytical framework", in: Allan

Bell and Peter Garrett (Eds), Approaches to Media Discourse, Oxford: Blackwell, pp. 142-62.

FAIRCLOUGH, NORMAN (2003) Analysing Discourse: textual analysis for social research, London: Routledge.

FLOWERDEW, JOHN (1999) “Description and Interpretation in Critical Discourse Analysis", Journal of Pragmatics 31, pp. 1089-99.

FOUCAULT, MICHEL (1984) "The Order of Discourse", in: Michael Shapiro (Ed.), Language and Politics, Oxford: Blackwell, pp. 108-38.

FOWLER, ROGER (1991) Language in the News: discourse and ideology in the press, London and New York: Routledge.

FOWLER, ROGER, HODGE, BOB, KRESS, GUNTHER and TREW, TONY (1979) Language and Control, London:

Routledge and Kegan Paul.

GAMSON, WILLIAM (1992) Talking Politics, Cambridge: Cambridge University Press.

GANS, HERBERT (1979) Deciding What's News: a study of CBS Evening News, NBC Nightly News, Newsweek and Time, New York: Pantheon.

GILL, ANN and WHEDBEE, KAREN (1997) "Rhetoric", in: Teun van Dijk (Ed.), Discourse as Structure and Process. Discourse studies. A multidisciplinary introduction, Vol. 1, London: Sage, pp. 15784.

GILL, ROSALIND (2000) “Discourse Analysis", in: Martin Bauer and George Gaskell (Eds), Qualitative Researching with Text, Image and Sound, London: Sage, pp. 172-90.

GLASGOW UNIVERSITY MEDIA GROUP (1980) More Bad News, London: Routledge and Kegan Paul. GRAMSCI, ANTONIO (1971) Prison Notebooks, New York: International Publishers.

HAJER, MAARTEN (1995) The Politics of Environmental Discourse: ecological modernization and the policy process, Oxford: Clarendon Press.

HALL, STUART, CRITCHER, CHARLES, JEFFERSON, TONY, CLARKE, JOHN and ROBERTS, BRIAN (1978) Policing the Crisis: mugging, the state, and law and order, London: Macmillan.

HALL, STUART, HOBSON, DOROTHY, LOWE, ANDREW and WILLIS, PAUL (Eds) (1980) Culture, Media, Language, London: Hutchinson.

HALLIDAY, MICHAEL (1978) Language as Social Semiotic, London: Edward Arnold.

HALLIDAY, MICHAEL (1985) Introduction to Functional Grammar, London: Edward Arnold. HARTLEY, JOHN (1982) Understanding News, London and New York: Routledge. HODGE, ROBERT and KRESS, GUNTHER (1988) Social Semiotics, London: Polity.

HYATT, DAVID (2005) "Time for a Change: a critical discoursal analysis of synchronic context with diachronic relevance", Discourse \& Society 16(4), pp. 515-34.

JACOBS, KEITH and MANZI, TONY (1996) "Discourse and Policy Change: the significance of language for housing research", Housing Studies 11(4), pp. 543-60.

KRESS, GUNTHER and VAN LEEUWEN, THEO (1990) Reading Images, Geelong, Vic.: Deakin University Press. 
MCCOMAS, KATHERINE and SHANAHAN, JAMES (1999) "Telling Stories About Global Climate Change: measuring the impact of narratives on issue cycles", Communication Research 26(1), pp. 30-57.

PHILO, GREG (2007) "Can Discourse Analysis Successfully Explain the Content of Media and Journalistic Practice?", Journalism Studies 8(2), pp. 175-96.

RICHARDSON, JOHN E. (2007) Analysing Newspapers: an approach from critical discourse analysis, Basingstoke: Palgrave Macmillan.

SPECTOR, MALCOLM and KITSUSE, JOHN (1977) Constructing Social Problems, Menlo Park, CA: Cummings.

STUBBS, MICHAEL (1997) "Whorf's Children: critical comments on critical discourse analysis", in: Ann Ryan and Alison Wray (Eds), Evolving Models of Language: papers from the 1996 annual meeting of BAAL, Milton Keynes: Multilingual Matters, pp. 100-16.

TOOLAN, MICHAEL (1997) "What is Critical Discourse Analysis and Why Are People Saying Such Terrible Things About It?", Language and Literature 6(2), pp. 83-103.

TYRWHITT-DRAKE, HUGH (1999) "Resisting the Discourse of Critical Discourse Analysis: reopening a Hong Kong case study", Journal of Pragmatics 31, pp. 1081-88.

VAN DIJK, TEUN (1988a) News Analysis: case studies of international and national news in the press, Hillsdale, NJ: Lawrence Erlbaum.

VAN DIJK, TEUN (1988b) News as Discourse, Hillsdale, NJ: Lawrence Erlbaum.

VAN DIJK, TEUN (1991) Racism and the Press, London: Routledge.

VAN DIJK, TEUN (1998) "Opinions and Ideologies in the Press", in: Allan Bell and Peter Garrett (Eds), Approaches to Media Discourse, Oxford: Blackwell, pp. 21-63.

VAN DIJK, TEUN (2001) "Critical Discourse Analysis", in: Deborah Tannen, Deborah Schiffrin and Heidi Hamilton (Eds), Handbook of Discourse Analysis, Oxford: Blackwell, pp. 352-71.

VAN DIJK, TEUN (2004) "Critical Context Studies", lecture given at CDA Conference, Valencia, May, http://www.discourses.org/UnpublishedArticles/Critical\%20context\%20studies.htm, accessed 17 May 2007.

VAN DIJK, TEUN (2005) Racism and Discourse in Spain and Latin America, Amsterdam: Benjamins. VAN DIJK, TEUN (2006) "Discourse and Manipulation", Discourse \& Society 17(3), pp. 359-83.

VAN LeEUWEN, THEO (1996) "The Representation of Social Actors", in: Carmen Rosa CaldasCoulthard and Malcolm Coulthard (Eds), Texts and Practices: readings in Critical Discourse Analysis, London: Routledge.

VAN LEEUWEN, THEO and WODAK, RUTH (1999) "Legitimizing Immigration Control: a discoursehistorical analysis", Discourse Studies 1(1), pp. 83-118.

WEISS, GILBERT and WODAK, RUTH (Eds) (2003) Critical Discourse Analysis: theory and interdisciplinarity, Basingstoke: Palgrave Macmillan.

WEYMOUTH, TONY (1998) "New Landscapes, Old Footpaths: the discourse of the written press revisited", Media, Culture and Society 20(3), pp. 499-506.

WHITE, DAVID (1950) "The Gatekeeper: a case study in the selection of news", Journalism Quarterly 27(4), pp. 383-90.

WIDDOWSON, HENRY (1995) "Discourse Analysis: a critical view", Language and Literature 4(3), pp. 157-72.

WODAK, RUTH (1996) Disorders of Discourse, London: Longman.

WODAK, RUTH (1999) "Critical Discourse Analysis at the End of the 20th Century", Research on Language and Social Interaction 32, pp. 185-93.

WODAK, RUTH and CHILTON, PAUL (Eds) (2005) A New Agenda for Critical Discourse Analysis: theory, methodology and interdisiciplinarity, Amsterdam: John Benjamins. 
WODAK, RUTH and MEYER, MICHAEL (2001) Methods of Critical Discourse Analysis, London: Sage. WODAK, RUTH, DE CILLIA, RUDOLF, REISIGL, MARTIN and LIEBHART, KARIN (Eds) (1999) The Discursive Construction of National Identity, Edinburgh: Edinburgh University Press.

Anabela Carvalho, Department of Communication Sciences, University of Minho, Campus de Gualtar, 4710-057 Braga, Portugal. E-mail: carvalho@ics.uminho.pt 